\title{
Analysis of Victim Cases Dental Technician in Health Law in Indonesia
}

\author{
Dara Chyntia Dewi \\ University of Airlangga, Indonesia \\ Email: ayudyadisti@gmail.com
}

\begin{tabular}{|c|c|}
\hline ARTICLE INFO & ABSTRACT \\
\hline $\begin{array}{l}\text { Date received : } 01 \text { January } 2021 \\
\text { Revision date : } 05 \text { February } 2021 \\
\text { Date received : } 02 \text { March } 2021\end{array}$ & $\begin{array}{l}\text { There are so many victims of dental technicians in Indonesia } \\
\text { that require special attention. The factor causing many } \\
\text { victims is the number of dental technicians who are illegal } \\
\text { and have exceeded the limit of authority that dentists should }\end{array}$ \\
\hline $\begin{array}{l}\text { Keywords: } \\
\text { Dental Technician } \\
\text { Health Law } \\
\text { Rules } \\
\text { Victims }\end{array}$ & $\begin{array}{l}\text { do. In fact, the authority of a dental technician is only limited } \\
\text { to making and installing removable dentures, but the fact is } \\
\text { that many dental technicians abuse the rules. This caused } \\
\text { many victims from minor illness to death. This is certainly not } \\
\text { in accordance with what is stated in the health law in } \\
\text { Indonesia. The government must be strict in enforcing } \\
\text { applicable health laws regarding dental technicians. }\end{array}$ \\
\hline
\end{tabular}

Coresponden Author:

Email: ayudyadisti@gmail.com

Article with open access under license

\section{INTRODUCTION}

Humans and medicine can not be separated from everyday life. This is because medicine is closely linked to health and sickness. Doctors are partners in social health whose aim is to preserve human health and restore human health. A doctor's essential position includes schooling long enough to be considered a doctor (Adisasmito, 2007).

Medical education with the fastest period of education of 5 to 6.5 years should be carried out. Medical students will study many medical books, conduct discussions, conduct operations, review journals, anatomy, physiology, disease, patient practice (OSCE), and so on in the first 4-4.5 years until they get S. Ked (Azizah, n.d.).

After the graduate, however, medical graduates were not permitted to practice medicine. 1-1.5 years of hospital education is required. They are called co-assistants for students who graduate from medicine. All knowledge is directly applied at this time, until graduation and getting the title of Dr. or Doctor. The doctor will conduct the service period after holding the title and account for the title he has. The average program for this specialization lasts about 4-5 years if they want to continue with specialist programs or deal with only one area of disease. The important role of doctors has caused many to want to enter the medical world (Pengertian IImu Kedokteran dan Lika-Liku Kuliah di Jurusan Ini, n.d.).

Being a doctor also has risks, one of which is malpractice, not infrequently. Malpractice is an act of professional negligence by a health care provider that causes the treatment provided to not conform to standard operating procedures, causing worsening medical conditions or even death (Dananjaya, Sutama, \& Priyanto, 2018). Postcesarean section infections that cause the stomach of a patient to be pierced, mismanagement of labour that causes the baby to experience a broken neck and peeling skin, blindness after an appendectomy, incorrect medication, blindness after birth, near loss of vital organs due to laser circumcision, and many more are some examples of terrible cases of malpractice. This has resulted in many individuals issuing opinions about perpetrators of malpractice who should be sued and convicted (Etika, 2007).

In dentistry, this can also occur. The dentist is a doctor with special oral health expertise. Dentistry is not only limited to teeth and mouth, but dental implants, abnormalities in the oral cavity, cleft lip disorders, tumors and cysts in the oral cavity or jaw, repair of the jawbone, and esthetic procedures are also treated by oral surgeons (SpBM). 
There are also a number of other dentistry specialists, including Orthodontics Specialist (SpOrt), Periodontist Specialist (SpPerio), Dental Conservation Specialist (SpKG), Pediatric Dentistry Specialist (SpKGA), Oral Disease Specialist (SpPM) and Dentist Specialist (SpRKG). Cavities, gum disease, oral cancer, sensitive teeth, and many more are diseases which dentists can handle. One important thing is to monitor the dentist. This is because the teeth and mouth are the primary organs that receive food and drink sources, so there are many opportunities for disease or abnormalities (Tobing, 2015).

The importance of this dentist also causes many cases of fraud to occur. One of them was a dentist who was abusing the rules. Dentists are only allowed to install loose dentures. Denture artisans generally have no formal education, only courses that cost around 7 million rupiahs. Based on Article 6 Paragraph (1) Permenkes 39/2014, the work of prosthetic dentists can only be carried out if it does not endanger health, does not cause illness and death, is safe, does not conflict with efforts to improve health status, and does not conflict with the norms and values that live in society. The work of prosthetic workers is limited to Article 6 Paragraph (2) Permenkes 39/2014 which only makes partial and/or full removable dentures made of heat curing acrylic which meets the health requirements, and installs partial and/or full removable teeth made of heat curing acrylic without covering the rest of the tooth root (Harahap, 2017). However, in the field of dental work, it is not uncommon to make mistakes that cause health impacts. The practice that was done was not in accordance with the regulations made; they even put on braces, made permanent dentures, removed teeth, filled teeth, and even whitened them. In addition, there have been many denture artisans who practice without a permit and are illegal. Many denture artisans are not competent but provide services like a dentist, as in the case of dentists who install loose dentures without removing the residue from the roots first (Savitri, 2018). This, of course, will cause abscess or pus. Therefore, the authors are interested in analyzing cases of denture prosthetic victims in Indonesia in health law (RUSTANDI, 2016).

\section{METODE}

This study uses a qualitative research method by obtaining secondary data from the internet that is credible and adjusted to the research title. The analysis technique used is a descriptive qualitative analysis technique, data processing by looking for an overview of the research data, comparing the data obtained and looking for the relationship between each data obtained so as to produce final conclusions about the research carried out.

\section{RESULTS AND DISCUSSION}

There are many cases associated with denture artisans that occur in Indonesia. For instance, for example, a dentist who performs installation services for braces, then there is an error causing the tooth to become infected. A perforated mouth, upward growing teeth, and even the severity of which causes death are other cases (Tobing, 2015). Article 276(2) states that 'Any person who, for a special or part-time livelihood, performs a job resembling a doctor or dentist shall be punished with imprisonment for a maximum of 5 (five) years or a maximum fine of Category $\mathrm{V}$ or 500 million. It is what caused the Union of Dentists to hold a protest against the Criminal Code Bill that takes into account the criminalization of dentists (SP, 2014).

People prefer to go to a dentist, even like the above, compared to a dentist who has a special certification, of course. The community's reasons vary, such as the price factor. Even though the risk value is sometimes ignored, professional work, and many more, the dentures' quality is the same. So far, dentists have only been treated by those who have a high economic status. Many Indonesians, meanwhile, fall into the lower average or middle to lower classes. Dentists are saying that unscientific dentists such as dentists have cheated society. However, the reality is that there are still denture craftsmen who make people satisfied and complain about nothing. The elimination of dentists also raises many questions because, because of the factors mentioned above, it is not certain that denture artisans' removal causes many individuals to turn to dentists, to return. However, if this continues, there will be even higher prosthetic artisan victims cases, as many do not have permits in Indonesia and abuse the authority regulated in the Permenkes. The regulations regarding dental technicians are in the laws and regulations Article 73 and Article 78 of Law Number 29 of 2004 concerning Medical Practice. This Law has undergone a revision through a Constitutional Court decision, which briefly states that dental technicians must be coached, not abolished. Apart from the Law, regulations regarding other dental artisans can be seen in the Minister of Health Regulation Number 39 of 2014 concerning Guidance, Supervision and Licensing, Dental technician jobs. Based on Article 1 , number 1 Permenkes 39 of 2014, a dental technician is any person who has the ability to make and install removable dentures (Lima Penyebab Tarif Perawatan Dokter Gigi Mahal Halaman all Kompasiana, n.d.). 
Based on the Permenkes, all dental technicians who carry out dental technician jobs are very obliged to register with the district or city government or to the district or city health office to obtain a dental technician license. This rule is in article 2 paragraph (1) Permenkes 39 of 2014. This dental technician license is given for 2 (two) years but can be extended as long as it meets the requirements. However, so far, many dental technicians are still illegal or have not registered themselves with the local government. Even these individuals confidently opened a dental technician clinic at a low price. Not only that, even if they broke the rules, there were dental technicians who used their abilities as doctors (SALIM, 2019).

Based on Article 9 Permenkes 39/2014, it is strictly regulated that dental technicians are strictly prohibited from doing work that is outside their authority. Apart from that, dental technicians are also prohibited from representing their work to other people, carrying out promotions that include jobs other than those regulated in Article 6 paragraph (2), and carrying out work on a mobile basis. Even if the dental technician violates these rules, the dental technician may be subject to administrative sanctions by the district or city government in the form of a written warning, temporary license revocation, and permanent license revocation (Tobing, 2015).

However, illegal dental technicians tend to ignore the rules above and want to reap as much profit as possible. This stems from the less strict arrangements for enrolling dental technicians. Therefore, one of the things that can be done is to revolutionize the arrangement of dental technicians. The government must act decisively and urge all regional governments to be firmer in granting permits.

The first thing is that if there are dental technicians who wish to register, they should do a more stringent test first. The test can be done with written and practical tests. The written exam contains the authority or knowledge of dental technicians. Then, the most important thing is to do a practical test. Through this test, the government can see whether it is feasible or not to be granted a permit. It is written, and practical test can certainly assess the ability of the dental technician. With this test, dental technicians who will apply will also be more careful and think twice about those who are not very good at teeth but want to become dental technicians.

The second thing is that the government can provide a letter of agreement in advance regarding dentists' practice. This letter contains an agreement not to abuse power and is ready to accept the government's consequences if there is a report. Concerning fines and penalties can also be stated in this agreement letter. Fines and penalties given are adjusted to the prevailing laws and regulations. However, this agreement letter is made more detailed and explained in advance after the dental technician has successfully passed the written exam and practical exam.

After the permit is granted, the local government must also continue to control and check the dental technician's practice. The government must continue to carry out evaluations through the community around dental technician practices. Matters regarding this supervision can also be stated in the agreement letter that was stipulated earlier. With this supervision, of course, the dental technician will feel that there is supervision and will be more careful in practising. This supervision is one of the most important ways because many think that after a permit is granted, it can be released just like that, even though there should still be control and evaluation from the local government. This supervision can be carried out periodically in accordance with the decisions of each region. For example, once every three months, but unknown to the dental technician, this ignorance makes the dental technician unprepared to show only the good things.

This incompetent ability causes many victims of dental technicians to experience severe side effects after fitting their teeth. Even these victims made Instagram accounts of dental technician victims, which had $113.9 \mathrm{k}$ followers and 821 posts. One of the viral posts was that a 40-year-old woman came to the dentist with complaints that her roots became increasingly visible after four months of putting braces at a dental technician. There is a tilt, but an unnatural roll, because it reaches the gums. It is caused by improper handling. The second severe case was a junior high school student with braces, but then his cheeks became swollen. The swelling is very large.

Not only that, but other severe cases are the palate becomes largely perforated as a result of permanent denture infection. There are also posts from Instagram victims of dental technicians whose victims died. A mother who died developed oral cancer after using dentures from dental technicians. His mouth cancer has already spread, making it difficult to save. Another victim who died was Sgt. Hartono, a member of Kodim 13403 South Sulawesi, who died after accidentally swallowing his dentures.

The victims above should be a reflection of the government because they have caused serious illness, even casualties. Dental technicians are styled like dentists who know many things. In fact, it is known that dentists need more than six years of education to obtain the title of doctor and dental specialist. Of course, this cannot be compared to a dental technician who has only undergone a few 
months of training. The tools used are sometimes not in accordance with the health standards applied by the government. Dental technicians also tend to abuse their authority often and do what dentists are supposed to do.

\section{CONCLUSION}

Based on the discussion, it can be concluded that there are many cases of dental technician victims who cause severe illness, even death. It is because dental technicians are not professional and often perform tasks outside of their authority. This is certainly not in accordance with what is stated in the health law in Indonesia. The government must be strict in enforcing applicable health laws regarding dental technicians. Another thing that can be done to reduce the risk of dental technician sacrifice is to certify that person who wants to become a dental technician profession. All training centres providing courses on dental technicians must be transformed and revolutionized greatly. To obtain a dental technician certification, you should not be fake but must use a strict selection. In providing training, educators must also instil ethics and morals in dental technicians. They are not easy to do things beyond their authority. Based on the above conclusions, the authors suggest that the government be able to make the best policies to tackle the rampant victims of dental technicians in Indonesia.

\section{REFERENCES}

Adisasmito, W. (2007). Sistem Kesehatan Nasional. Jakarta: PT. Rajagrafindo Persada.

Azizah. (n.d.). Tukang Gigi Demo Tolak RUU KUHP, Berikut Aturan Praktek Tukang Gigi.

Dananjaya, I. Gede Wahyu, Sutama, Ida Bagus Putu, \& Priyanto, I. Made Dedy. (2018). PERLINDUNGAN HUKUM TERHADAP KONSUMEN YANG DIRUGIKAN ATAS JASA PRAKTEK TUKANG GIGI DI KOTA DENPASAR. Kertha Semaya: Journal IImu Hukum; Vol. 01, No. 10, Oktober 2013.
Retrieved

from https://ojs.unud.ac.id/index.php/kerthasemaya/ article/view/42042

Etika, S. A. (2007). Hukum kesehatan.

Harahap, R. A. (2017). Etika dan Hukum Kesehatan.

Lima Penyebab Tarif Perawatan Dokter Gigi Mahal Halaman all - Kompasiana. (n.d.).

Pengertian IImu Kedokteran dan Lika-Liku Kuliah di Jurusan Ini. (n.d.).

RUSTANDI, RIFKY RAMADHAN. (2016). PERLINDUNGAN HUKUM PASIEN PENGGUNA KAWAT GIGI MELALUI JASA TUKANG GIGI SECARA ONLINE DIHUBUNGKAN DENGAN UNDANGUNDANG NOMOR 8 TAHUN 1999 TENTANG PERLINDUNGAN KONSUMEN JUNCTIS UNDANG-UNDANG NOMOR 36 TAHUN 2009 TENTANG KESEHATAN, DAN UNDANG-UNDANG NOMOR 11. Universitas Pasundan.

SALIM, N. K. (2019). PENEGAKAN HUKUM TERHADAP OKNUM YANG MELAKUKAN PRAKTIK ILEGAL PEMASANGAN KAWAT GIGI BERDASARKAN HUKUM POSITIF INDONESIA DI KOTA PALEMBANG. Universitas Muhammadiyah Palembang.

Savitri, Mutia Arum. (2018). HUBUNGAN DESAIN INTERIOR KLINIK GIGI TERHADAP KECEMASAN PASIEN SEBELUM PERAWATAN GIGI DAN MULUT. Fakultas Kedokteran Gigi UNISSULA.

SP, Andi. (2014). Pola Perilaku Anak Terhadap Perawatan Gigi dan Mulut [Skripsi]. Makassar: Fakultas Kedokteran Gigi Universitas Hasanuddin.

Tobing, Letezia. (2015). Ulasan lengkap: Kewenangan Tukang Gigi. Hukumonline.Com. Retrieved from https://www.hukumonline.com/klinik/detail/ulas an/lt54dcda3fcc3e1/kewenangan-tukang-gigi/ 